\title{
Effect of Teaching Guidelines on self-efficacy for Patients with End Stage Renal Disease Undergoing Hemodialysis
}

\author{
Aml Ahmed Mohammed El-Metwaly ${ }^{1}$, Dr. Bahia Galal Abd-El Razik ${ }^{2}$, Ass. Prof. \\ Ahmed Farouk Donia ${ }^{3}$ and Prof. Dr. Magda Abdel Aziz Mohammed ${ }^{4}$ \\ ${ }^{1}$ Ass. Lecturer- Faculty of Nursing-Mansoura University; ${ }^{2}$ Lecturer of Medical \\ Surgical Nursing-Faculty of Nursing-Port Said University; ${ }^{3}$ Assistant Professor of \\ Nephrology-Urology and Nephrology center-Mansoura University; ${ }^{4}$ Professor of \\ Medical Surgical Nursing-Faculty of Nursing-Ain Shams University, Egypt.
}

\begin{abstract}
Background: End stage renal disease (ESRD) could be developed with or without the risk factors. However, the more risk factors presented the greater likelihood of developing ESRD. The aim of the present study was to evaluate the effect of teaching guidelines on self-efficacy for patients with end stage renal disease. Research design used was Quasi experimental research design utilized in this study. The study was carried out at Urology and Nephrology Center of Mansoura University. A purposive sample including 80 Egyptian patients with ESRD on Hemodialysis therapy. Two tools were used in data collection; Tool I a structured Questionnaire tool, Tool II Chronic Kidney Disease- Self Efficacy (CKD- SE) Scale. The Result of the study reveals that there were high statistical significant differences in study subjects' Mean Scores of four domains of CKD-SE scale between Pre and Post implementation of the teaching guidelines. Conclusion: It can be concluded that patients with ESRD treated with Hemodialysis tended to have higher scores (better SE) post implementation of teaching guidelines. Recommendations: Replication and expanded studies are needed for hemodialysis patients. Future studies should try to incorporate prospective data collection, long term follow-up and validated disease specific SE instruments.
\end{abstract}

Keywords: End stage renal disease, Hemodialysis, Self-efficacy Teaching guidelines 


\section{INTRODUCTION}

End-stage renal disease (ESRD) is the last stage of chronic kidney disease. When kidneys fail, it means they have stopped working well enough for one to survive without dialysis or a kidney transplant (American Kidney Fund, 2016).

End-stage renal disease (ESRD) has significantly increased in developing countries such as Egypt. Diabetes mellitus is still the leading cause of ESRD, while numbers of hypertensive patients among that population have significantly risen. Costs for dialysis and renal transplantation are still unaffordable in Egypt for most patients with ESRD. Since the cost burden has significantly increased, nephrology services should be changed from curative medicine to preventive medicine (Soliman, et al., 2012).

Hemodialysis is the most common form of medical management of patients affected by end-stage renal disease (ESRD). For hemodialysis to be successful, strict fluid and weight control is recommended. Education, in terms of self-care activities, is an important intervention for improving patients' outcomes (Aliasgharpour, et al., 2012).

Self-efficacy relates to a person's perception of their ability to reach a goal and the belief that one is capable of performing in a certain manner to attain certain goals.It is the expectation that one can master a situation, and produce a positive outcome Selfefficacy is an important concept in positive psychology (Bandura, 1982).

Self-efficacy theory was originated from Social Cognitive theory by Alberta Bendura. It is the belief that one has the power to produce that effect by completing a given task or activity related to that competency enhancing the perception of selfefficacy has a positive effect on an engaging in health-promoting behaviors, motivation, thinking style, and state of emotional wellness and coping with chronic physical illnesses (Akin, et al., 2009\& Bandura, 1982).

Numerous evidences have suggested that the empowerment of ESRD patients treated with HD are associated with outcomes such as improvements in self-care, effective management of illness-related problems, and appropriate decision making. These outcomes are somehow related to the concept of self-efficacy (Heidari, et al., $2007 \&$ Thomas-Hawkins and Zazworsky, 2005). 


\section{AIM OF STUDY:}

\section{This study aims to:}

Evaluate the effect of teaching guidelines on Self-efficacy for patients with end stage renal disease through:

- Assessing self-efficacy of patients with end stage renal disease.

- Developing and implementing teaching guidelines regarding end stage renal disease based on needs assessment.

-Evaluating the effect of applying teaching guidelines on self-efficacy for patients with end stage renal disease.

\section{Hypotheses:}

To achieve the aim of this study the following research hypothesis was formulated:

- Teaching guidelines will significantly increase patient's self- efficacy scores after the implementation of the teaching guidelines.

\section{SUBJECTS AND METHOD:}

1. Technical design: The technical design includes; the research design, study setting, subjects, and tools for data collection.

Research design: A Quasi experimental research design was used in this study.

Setting: The present study was conducted at Hemodialysis units at Mansoura Urology and Nephrology Center.

Subjects: A purposive sample including 80 Egyptian patients with ESRD on Hemodialysis therapy. All Adult patients with ESRD on hemodialysis therapy aged between 20-60 years old. Patients with clinical evidence of malignances, handicaps, paralysis, cerebral stroke are excluded. Patients who are unable to communicate also excluded from the sample.

Tools for data collection: Two tools were used in data collection:

\section{Tool I: A structured Questionnaire:}

An Arabic questionnaire sheet was developed by the researcher; it is divided into the following parts:

Part one: Demographic data consists of patient's age, sex, level of education, occupation, marital status, residence and monthly income. It is composed of (9) closed ended question. 
Part two: Patient's medical history which consists of past medical history, present medical history and family history.

- Past medical history: It is composed of 7 questions including 2 open ended questions about duration of disease(in years) and duration of transplantation and 5 closed ended questions about associated chronic diseases, number of hospitalization during the last six months with its causes and history of renal transplantation.

- Present medical history of the patients: It is composed of 13 questions including (8) open ended questions about: duration of dialysis, number of vascular access, physical assessment as: (vital signs, body weight, height, body mass index, dialysis adequacy index and laboratory investigations) and (5) closed ended questions about: number of hemodialysis sessions/week, duration of dialysis session, types of vascular access, occurrence of complications due to ESRD, urination problems.

- Family history including: presence of renal failure in the family and degree of relation. It is composed of (2) closed ended questions.

\section{Tool II: Chronic Kidney Disease- Self Efficacy (CKD- SE) Scale}

The CKD- SE scale was developed by (Lin, et al., 2012). The CKD- SE scale was translated into Arabic language then retranslated again into English languages to detect any changes in meanings.

The CKD- SE scale consists of (25) items divided into four factors: Autonomy (8 questions), Self-integration(7 questions), Problem solving(6 questions) and seeking social support(4 questions) to measure patients' perceived disease-related self-efficacy (DSE).

Chronic Kidney Disease- Self Efficacy (CKD- SE) Scale scoring system:

The score for each item is the number circled. If two consecutive numbers are circled, code the lower number (less self-efficacy). If the numbers are not consecutive, do not score the item. The score for each scale is the mean of the items. For scales of 1-2 items, do not score the scale if any item is missing; for scales with 3-4 items, do not score the scale if more than 1 item is missing; for scales with 5-6 items, do not score 
the scale if more than 2 items are missing. Higher number indicates higher selfefficacy.

The scores of the domains items were summed up and the total divided by the number of the items, giving a mean score.

\section{Operational design:}

The operational design consists of preparatory phase, content validity, pilot study, field work, operational definitions, and limitation of the study.

\section{Preparatory phase:}

The first step of this phase was concerned with the review of literature related to ESRD and theoretical knowledge of the various aspects of the self-efficacy for these patients using books, articles, periodicals and Medline search to develop the study tools for data collection.

The second step of this phase was concerned with assessment of expertise opinions about aspects of the developed tools and various parts of the proposed patient guidelines for patient with ESRD.

\section{Content Validity \& reliability:}

Content validity was conducted to test the tool for appropriateness, relevance, correction and clearance through a jury of seven experts: from medical surgical nursing staff at the faculty of nursing (Jury was done from different academic categories (professors and assistant professors)., one from Port Said University, two from Ain Shams University and three from Mansoura University and assistant professor of urology from urology and nephrology center at Mansoura University.

Test reliability of the proposed tools was done by cronbach's alpha test, showed a strong significant positive correlation between test (A) and retest (B) in knowledge, practice and attitude items.

\section{Pilot study:}

The pilot study was applied on (8) patients $(10 \%)$ within the selected criteria to test the applicability of tools, arrangement of items, and estimate the time needed for each sheet, and then excluded from the study sample after modification of the tools.

\section{Field Work:}

The selection of the patients, the collection of data, and the implementation of the teaching guidelines lasted over a period of (6)months starting from March 2015 to September 2015 for hemodialysis patients. The researcher recruited them from the two 
work shifts (morning and afternoon) at Hemodialysis units at Mansoura Urology and Nephrology Center.

The data collection was done after starting hemodialysis session by one hour to confirm patient's ability to concentrate and relieve the signs of azotemia.

\section{The study consists of two phases:}

pre phase of assessment: This phase was done prior of conducting the teaching guidelines to the patients using two tools

The $1^{\text {st }}$ session: included interviewing the patients regarding Demographic characteristics, past, present and family history, checking vital signs obtaining physical assessment and laboratory investigations.

Time allowed: from 20- 30 minutes for each patient.

The $2^{\text {nd }}$ session included assessment of patients' self-efficacy.

Time allowed: from 30- 40 minutes.

From $3^{\text {rd }}$ to $5^{\text {th }}$ session (the sessions): the teaching guideline was developed by the researcher after determining patients' needs and review of related literature. It was applied through patients teaching sessions using questions, discussion, demonstration and re-demonstration aided by using booklets, illustrative pictures and handouts. These teaching guidelines consisted of 3 sessions; each session lasted about 60 minutes and was accompanied by feedbacks.

Teaching guidelines was applied during hemodialysis sessions and were done either individually or in groups (3-4) patients.

Post phase of assessment: This session included reassessment of patients' Selfefficacy after applying the teaching guidelines.

\section{III-Administrative design}

An official permission was obtained from director of Mansoura Urology and Nephrology Center based on a letter that issued to him from Dean of faculty of Nursing Port Said University and before conducting the study explaining the aim of the study to obtain the permission for data collection. They were given an opportunity to refuse the participation, and they were assured that there information which would be used for research purposes only.

\section{Ethical consideration:}

All ethical issues were taken into consideration during all phases of the study. The ethical research considerations in this study included the following: The research 
approval was obtained before guidelines implementation, the objectives and the aim of the study were explained to the participants, the research maintains on anonymity and confidentiality of subjects, and subjects were allowed to choose to participate or not and they have the right to withdrawal from the study at any time without penalty.

\section{IV-Statistical analysis}

All collected data were organized, categorized, tabulated, entered, and analyzed by using SPSS, (Statistical Package for Social Sciences), soft-ware program version 15, which was applied to frequency tables, statistical significance and associations were assessed using the arithmetic mean, standard deviation (SD), student t-test, anova test, and coefficient correlation ( $r$ ) to detect the relations between the variables.

Non significant (NS) $\quad \mathrm{p}>0.05$

Significant (S)

$\mathrm{p} \leq 0.05$

Highly significant (HS)

$$
\mathrm{P}<0.001
$$

\section{RESULTS:}

Table 1: shows that the mean age for the study subjects was $41.7 \pm 13.2$ years. Males were predominate in the group $62 \%$, and $61.3 \%$ of them were married. The $45 \%$ of the study subjects had Secondary degree education and $65 \%$ of them were not working. Also, $57.5 \%$ of the study subjects had inadequate monthly income.

Table 2: shows that all the entire study subjects attends three times/ week to hemodialysis sessions and $78.8 \%$ of them spending four hours on the session. As regard to vascular access, it was noticed that $85 \%$ of the study subjects had fistula as well as $91.2 \%$ of them performed the access (1-4) times. $81.3 \%$ of the entire study subjects suffer from anuria, while $18.8 \%$ of them suffer from oliguria.

Table 3: illustrates that there were high statistical significant differences in all items of autonomy domain total scores of the study subjects' between Pre and Post implementation of the teaching guidelines with $(\mathrm{p} \leq 0.001)$ with significant increase in their mean scores.

Table 4: shows that there were high statistical significant differences in study subjects' self-integration domain scores between Pre and Post implementation of the teaching guidelines with $(\mathrm{p} \leq 0.001)$ with significant increase in their mean scores. 
Table 5: shows that there were high statistical significant differences in study subjects' Problem solving domain scores between Pre and Post implementation of the teaching guidelines with $(\mathrm{p} \leq 0.001)$ with significant increase in their mean scores.

Table 6: reveals that there were high statistical significant differences in study subjects' Seeking social support domain scores between Pre and Post implementation of the teaching guidelines with $(\mathrm{p} \leq 0.001)$ with significant increase in their mean scores.

Figure 1: illustrates that, the major associated CKD complications were for fatigue, anemia, cramps and sleeping troubles $(75 \%, 67.5 \%, 65 \%$ and $58.8 \%$ respectively).

Figure 2: reveals that $(25.0 \%)$ of the study subjects have positive family history to renal failure, where $(75.0 \%)$ of them with first-degree relatives.

Figure 3: reveals that there were high statistical significant differences in study subjects' Mean Scores of four domains of CKD-SE scale between Pre and Post implementation of the teaching guidelines with $(p \leq 0.001)$. 
Table (1): Percentage Distribution of Study Subjects according to their Demographic Characteristics.

\begin{tabular}{|c|c|c|}
\hline $\begin{array}{c}\text { Demographic } \\
\text { Characteristics }\end{array}$ & No. $=80$ & $\%$ \\
\hline Age Distribution (in years) & & \\
\hline$<20$ & 3 & 3.8 \\
\hline $21-30$ & 15 & 18.8 \\
\hline $31-40$ & 23 & 28.8 \\
\hline $41-50$ & 20 & 25 \\
\hline $50-60$ & 11 & 13.8 \\
\hline$>60$ & 8 & 10 \\
\hline$($ mean \pm SD $)$ & \multicolumn{2}{|c|}{$41.7 \pm 13.2$} \\
\hline Sex & & \\
\hline Females & 30 & 37.5 \\
\hline Males & 50 & 62.5 \\
\hline \multicolumn{3}{|l|}{ Marital status } \\
\hline Single & 15 & 18.8 \\
\hline Married & 49 & 61.3 \\
\hline Divorced & 11 & 13.8 \\
\hline Widowed & 5 & 6.3 \\
\hline \multicolumn{3}{|l|}{ Educational level } \\
\hline Illiterate & 11 & 13.8their \\
\hline Read and write & 9 & 11.3 \\
\hline Secondary degree & 36 & 45.0 \\
\hline University & 24 & 30.0 \\
\hline \multicolumn{3}{|l|}{ Occupational status } \\
\hline Governmental & 9 & 11.3 \\
\hline Private & 19 & 23.8 \\
\hline Not working & 52 & 65 \\
\hline \multicolumn{3}{|l|}{ Monthly income } \\
\hline Enough & 34 & 42.5 \\
\hline Not enough & 46 & 57.5 \\
\hline
\end{tabular}


Table (2): Distribution of the Study Subjects Regarding to their Present Health

History.

\begin{tabular}{|l|c|c|}
\hline \multicolumn{1}{|c|}{ Present Health History } & No. $=\mathbf{8 0}$ & $\mathbf{\%}$ \\
\hline Frequency of weekly hemodialysis sessions & & \\
Two times /week & 0 & 0 \\
Three times /week & 80 & $\mathbf{1 0 0}$ \\
\hline Duration of hemodialysis session & 7 & \\
3 hours & 10 & 12.5 \\
3.5 hours & 63 & $\mathbf{7 8 . 8}$ \\
4 hours & & \\
\hline Type of vascular access & 68 & $\mathbf{8 5 . 0}$ \\
Fistula & 9 & 11.3 \\
Graft & 3 & 3.8 \\
Catheter & & \\
\hline
\end{tabular}

Table (3): Mean Scores, Standard Deviations and Tests of Significance of CKD-SE scale (Autonomy domain).

\begin{tabular}{|l|c|c|c|c|}
\hline \multicolumn{1}{|c|}{ CKD-SE scale } & Pre & Post & \multicolumn{2}{l|}{ Student's t test } \\
\hline \multicolumn{1}{|c|}{ Autonomy } & Mean \pm SD & Mean \pm SD & T & P \\
\hline $1 . \quad$ I can accept having CKD & $4.58 \pm 1.49$ & $6.08 \pm 1.3$ & 6.783 & $<0.001$ \\
\hline $\begin{array}{l}\text { 2. I comfortable telling a } \\
\text { physician that I have CKD }\end{array}$ & $4.88 \pm 1.37$ & $6.54 \pm 1.05$ & 8.592 & $<0.001$ \\
\hline $\begin{array}{l}\text { 3. I can face the challenges of } \\
\text { living with CKD }\end{array}$ & $3.61 \pm 1.32$ & $5.23 \pm 0.86$ & 9.181 & $<0.001$ \\
\hline $\begin{array}{l}4 . \quad \text { I am comfortable telling others } \\
\text { that I have CKD }\end{array}$ & $3.61 \pm 1.36$ & $5.51 \pm 0.95$ & 10.207 & $<0.001$ \\
\hline $\begin{array}{l}5 . \quad \text { I can do whatever is necessary } \\
\text { to have my questions about my CKD } \\
\text { answered }\end{array}$ & $4.16 \pm 1.12$ & $5.71 \pm 1$ & 9.255 & $<0.001$ \\
\hline $\begin{array}{l}\text { 6. I am comfortable contacting my } \\
\text { doctor at any time with questions about } \\
\text { my medication }\end{array}$ & $5.43 \pm 1.28$ & $6.9 \pm 1$ & 8.155 & $<0.001$ \\
\hline $\begin{array}{l}7 . \quad \text { I can comfortably ask providers } \\
\text { about my current disease condition }\end{array}$ & $5.25 \pm 1.24$ & $6.24 \pm 0.86$ & 5.860 & $<0.001$ \\
\hline $\begin{array}{l}8 . \quad \text { I can actively share my } \\
\text { experience of managing the CKD with } \\
\text { others study subjects }\end{array}$ & $3.03 \pm 1.27$ & $5.24 \pm 0.93$ & 12.550 & $<0.001$ \\
\hline Autonomy total score & $34.54 \pm 8.13$ & $47.44 \pm 4.98$ & 12.103 & $<0.001$ \\
\hline
\end{tabular}


Table (4): Mean Scores, Standard Deviations and Tests of Significance of CKD-SE scale (Self-integration domain).

\begin{tabular}{|l|l|l|l|l|}
\hline \multicolumn{1}{|c|}{ CKD-SE scale } & Pre & Post & \multicolumn{2}{l|}{ Student's t test } \\
\hline \multicolumn{1}{|c|}{ Selintegration can manage my diet in a } \\
\hline $\begin{array}{l}1 . \quad 3.84 \pm 1.28 \\
\text { variety of social situations in order not } \\
\text { to increase the workload of my kidney }\end{array}$ & $5.85 \pm 0.98$ & 11.691 & $<0.001$ \\
\hline $\begin{array}{l}2 . \quad \text { I can adhere to my diet plan } \\
\text { recommendations even when I eat out }\end{array}$ & $3.7 \pm 1.23$ & $5.68 \pm 0.88$ & 12.081 & $<0.001$ \\
\hline $\begin{array}{l}\text { 3. I can choose appropriate foods } \\
\text { during social activities }\end{array}$ & $3.38 \pm 1.08$ & $5.18 \pm 0.78$ & 15.259 & $<0.001$ \\
\hline $\begin{array}{l}4 . \quad \text { I can adjust the self- } \\
\text { management of my CKD to fit new } \\
\text { situations }\end{array}$ & $3.54 \pm 1.07$ & $5.74 \pm 0.72$ & 13.829 & $<0.001$ \\
\hline $\begin{array}{l}5 . \quad \text { I can make dietary changes } \\
\text { when advised to do so by my provider }\end{array}$ & $3.8 \pm 1.08$ & $6.01 \pm 0.93$ & 13.226 & $<0.001$ \\
\hline $\begin{array}{l}\text { 6. I can manage my CKD in order } \\
\text { to stay healthy }\end{array}$ & $4.28 \pm 0.94$ & $6.29 \pm 0.98$ & 8.584 & $<0.001$ \\
\hline $\begin{array}{l}\text { 7. I can participate in appropriate } \\
\text { social activities }\end{array}$ & $3.28 \pm 1.4$ & $5.01 \pm 1.15$ & 17.440 & $<0.001$ \\
\hline Self-integration total score & $25.8 \pm 6.33$ & $39.75 \pm 3.34$ & 12.103 & $<0.001$ \\
\hline
\end{tabular}

Table (5): Mean Scores, Standard Deviations and Tests of Significance of CKD-SE scale (Problem solving domain).

\begin{tabular}{|l|l|l|l|l|}
\hline \multicolumn{1}{|c|}{ CKD-SE scale } & Pre & Post & \multicolumn{2}{l|}{ Student's t test } \\
\hline \multicolumn{1}{|c|}{ Problem solving } & Mean \pm SD & Mean \pm SD & T & P \\
\hline $\begin{array}{l}\text { 1. I understand the meaning of } \\
\text { relevant laboratory data }\end{array}$ & $2.65 \pm 1.49$ & $4.30 \pm 1.26$ & 7.561 & $<0.001$ \\
\hline $\begin{array}{l}\text { 2. I can seek out information that } \\
\text { explains CKD-related signs and } \\
\text { symptoms }\end{array}$ & $2.5 \pm 1.46$ & $4.68 \pm 1.49$ & 9.329 & $<0.001$ \\
\hline $\begin{array}{l}\text { 3. I can find information about } \\
\text { kidney disease from a variety of sources }\end{array}$ & $2.33 \pm 1.36$ & $4.74 \pm 1.28$ & 11.565 & $<0.001$ \\
\hline $\begin{array}{l}4 . \quad \text { I can actively understand the } \\
\text { risk factors associated with CKD }\end{array}$ & $2.63 \pm 1.3$ & $5.51 \pm 1.01$ & 15.738 & $<0.001$ \\
\hline $\begin{array}{l}\text { 5. I can find resources needed to } \\
\text { better control my CKD }\end{array}$ & $2.49 \pm 1.17$ & $5.16 \pm 1.01$ & 15.474 & $<0.001$ \\
\hline $\begin{array}{l}\text { 6. I can actively seek out necessary } \\
\text { precautions to prevent my CKD from } \\
\text { worsening }\end{array}$ & $3.09 \pm 1.1$ & $5.38 \pm 0.83$ & 14.729 & $<0.001$ \\
\hline Problem solving total score & $15.68 \pm 7.03$ & $29.76 \pm 1.6$ & 15.006 & $<0.001$ \\
\hline
\end{tabular}


Table (6): Mean Scores, Standard Deviations and Tests of Significance of CKD-SE scale (Seeking social support domain).

\begin{tabular}{|l|l|l|l|c|}
\hline \multicolumn{1}{|c|}{ CKD-SE scale } & Pre & Post & \multicolumn{2}{l|}{ Student's t test } \\
\hline \multicolumn{1}{|c|}{ Seeking social support } & Mean \pm SD & Mean \pm SD & T & P \\
\hline $\begin{array}{l}\text { 1. I can find help when I am } \\
\text { feeling stressed }\end{array}$ & $5.31 \pm 1.01$ & $6.51 \pm 0.83$ & 8.205 & $<0.001$ \\
\hline $\begin{array}{l}\text { 2. I can discuss my questions and } \\
\text { worries about the CKD with my family } \\
\text { and/or friends }\end{array}$ & $5.24 \pm 0.88$ & $6.64 \pm 0.85$ & 10.291 & $<0.001$ \\
\hline $\begin{array}{l}\text { 3. I can ask family or friends for } \\
\text { help when I am feeling helpless or } \\
\text { frustrated }\end{array}$ & $5.2 \pm 0.96$ & $6.31 \pm 1.11$ & 6.783 & $<0.001$ \\
\hline $\begin{array}{l}\text { 4. I can actively discuss my } \\
\text { treatment plan with my family and/or } \\
\text { friends to gain their support. }\end{array}$ & $4.95 \pm 0.98$ & $6.14 \pm 1$ & 7.576 & $<0.001$ \\
\hline Seeking social support total score & $20.7 \pm 3.37$ & $25.6 \pm 2.67$ & 10.202 & $<0.001$ \\
\hline
\end{tabular}

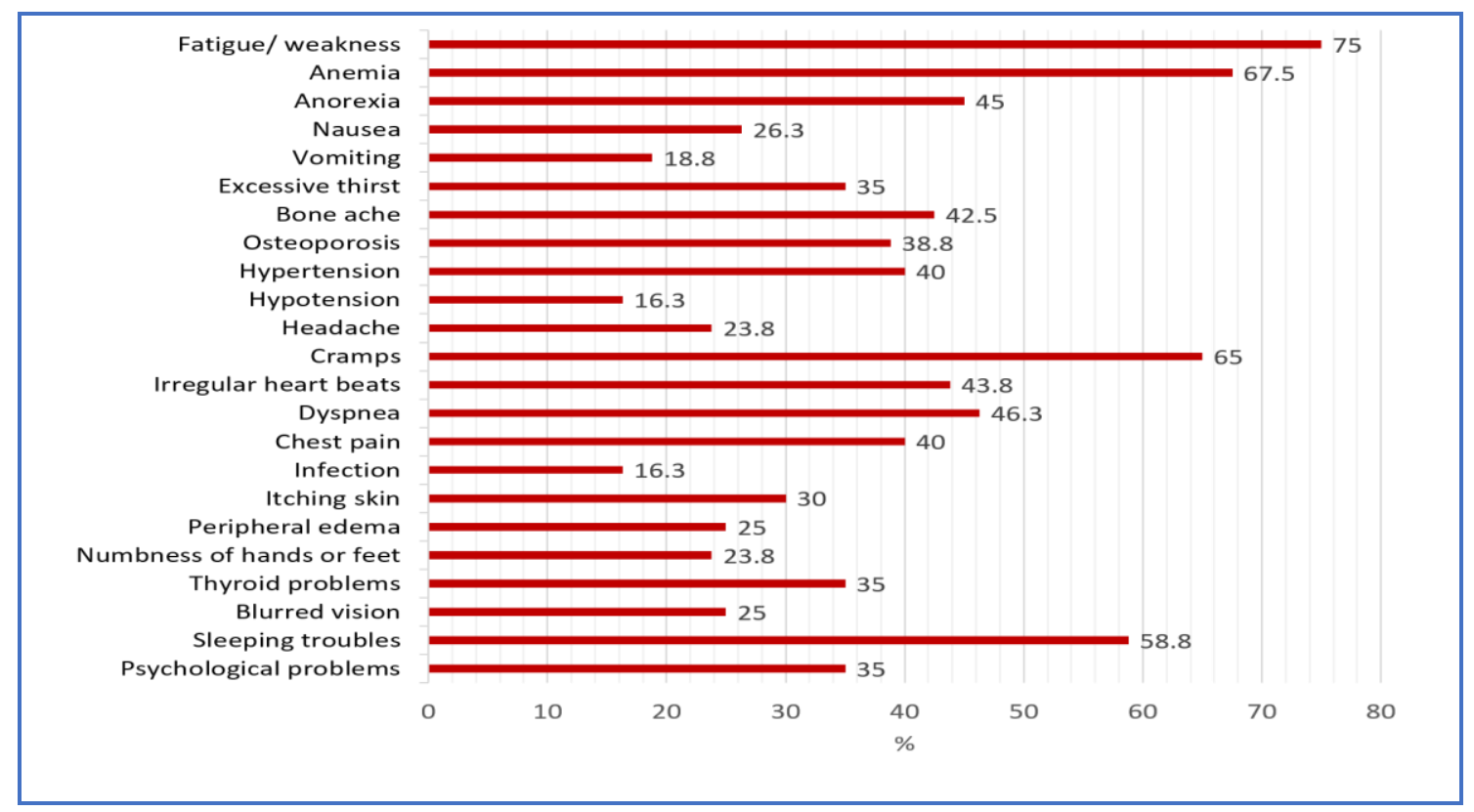

Figure (1): Distribution of the Study Subjects Regarding to Chronic Kidney Disease Complication. 


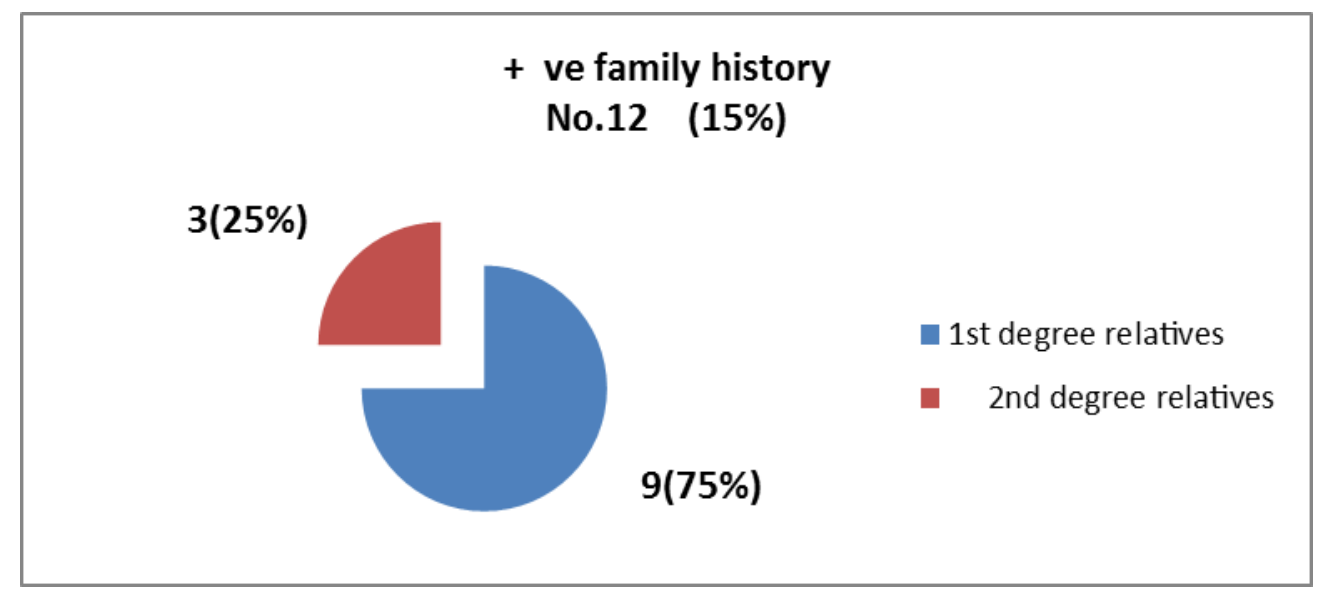

Figure (2): Distribution of the Study Subjects Regarding to their family History of Renal Failure

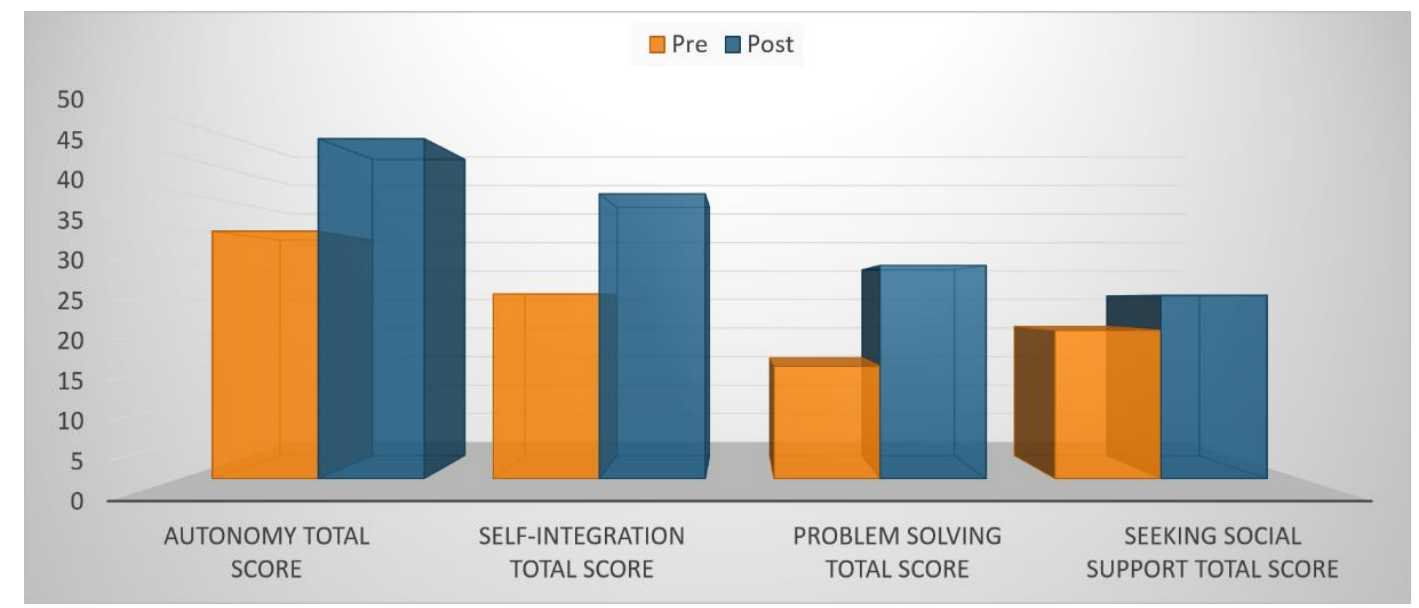

Figure (3): Mean Scores of four domains of CKD-SE scale Pre and Post Implementation of the Teaching Guidelines.

\section{DISCUSSION:}

Patients with end-stage renal disease often fail to follow a prescribed diet and fluid regimen, which undermines the effectiveness of care and leads to unpredictable progression of the disease and greater likelihood of complications. These patients require major lifestyle changes and self-efficacy to comply with the treatment regimen of their chronic illness. A person with an increased perception of selfefficacy is more likely to participate in self-care activities and thus increase their adherence to the treatment regimen (Tsay, 2003). 
In the current study, the researcher chose to use Chronic Kidney Disease- Self Efficacy (CKD- SE) Scale. CKD- SE Scale may be criticized by non specificity and its deficiency in addressing important issues for hemodialysis patients. However the researcher had proceeded to use it because, CKD- SE Scale four domains are more comprehensive and cover all aspects of physical, social and emotional life.

Concerning age, the finding of the present study revealed that The mean age \pm SD (range) for the study subjects was $41.7 \pm 13.2$ (31-40 years). This finding is in agreement with Badheeb, (2006) who revealed that, the mean age range of the HD patients was 42 years as $29.4 \%$ of patients aged between (31 to 40 ) years. These findings also supported by Mohammad, (2007), who mentioned that age increases more the likelihood to have ESRD, as it is uncommon in individuals younger than eighteen years.

Regarding to gender, the present study clarified that, more than three fourth of the study subject were males. This result is in accordance with Shinde and Mane, (2014) found regarding to the sex majority of the patients was male.

Concerning marital status, the results of the current study revealed that the majority of the study subjects were married. This may be due to that the majority of the study subjects were over thirty years and according to the Egyptian society culture, by this age they are married. These findings are in the same line with Mohammad, (2007) and Lutf, (2007), who mentioned that their majority of the study subjects were married.

As regards to educational level, the result of this study showed that nearly half of patients shared in study had Intermediate degree. These findings aren't in agreement with Abd-El hamed, (2011) and Lutf, (2007), who found that above (one third and two third) respectively of the study subjects, had basic education. Concerning occupation, the present study showed that more than half of the study subject weren't working, this findings could be due to the fact that the subjects that didn't work were within age $>60$ years old which is considered the age of retirement in Egypt and large number of females were house wives also many factors such as fatigue, tiredness and the disability caused by the disease must be taken into consideration. This finding goes on the same line with Abd- Elazeem, (2008) and Sharaf, et al, (2004) who found that the majority of their subjects were not working. 
In relation to HD frequency and duration, the current study clarified that, the entire studied subjects attends three times/ week to hemodialysis sessions and the majority of them spending four hours on the session. This finding is supported by Ahmed, et al., (2010) who mentioned that, the main hemodialysis regimen adopted in Egypt is three times per week.

As regard to vascular access used, the majority of studied subjects having fistula and performed the access from one to four times. These results come in consistent with Abd-El hamed," (2011) findings. Anees, et al. (2011), recommended that, arteriovenous fistula is considered the optimal form of vascular access for patients who have ESRD and receive hemodialysis. As well, he found majority of hemodialysis patients had AVF and Afifi, et al., (2002) who studied one thousand hemodialysis patients in eighteen dialysis centers in Egypt reveal that 93\% of the patients had natural arteriovenous access while $7 \%$ had synthetic arteriovenous grafts. As regard to chronic kidney disease complications, the present study revealed that, the major associated CKD complications were for fatigue, anemia, cramps and sleeping troubles. These results are in the same direction with Weisbord et al., (2007) and Tsay,(2003). In addition Hammed, (2001) mentioned that the primary hematological effect of renal failure was anemia.

Also, youssif, (2009), Added that three fourth of study subject suffering from muscle cramps. This may be due to increase ultrafiltration rate causing rapid fluid shifting (rapid removal of sodium and water) and Mohammad, (2007) mentioned that predisposing factors of cramps are hypotension, being below dry weight and usage of low sodium dialysis solutions.

Concerning family history, the present study clarified that less than quarter of the study subject has positive family history. This result is in the same line with $E \boldsymbol{l}$ Sayed, (2007), who found that the majority of his study subjects had no family history.

Concerning total SE of the study subjects, the present study demonstrates that there were high statistical significant differences in total SE of the study subjects with significant increase in their mean scores. This result is supported by Aliasgharpour, et al., (2012), who shows that implementing a self-efficacy promotion training programme is effective in increasing self-efficacy in patients undergoing hemodialysis. In addition, Tsay, (2003) supports in his study the effectiveness of the self-efficacy training with end-stage renal disease patients receiving hemodialysis. 
Song, (2000), found that the self-efficacy promotion program for hemodialysis patients was effective to improve degree of specific self-efficacy and self-care.

\section{CONCLUSION:}

Based on study findings, it can be concluded that: patients with ESRD treated with Hemodialysis tended to have higher scores (better SE) post implementation of teaching guidelines in all domains as there were high statistical significant differences in study subjects' Mean Scores of four domains of CKD-SE scale between Pre and Post implementation of the teaching guidelines

\section{RECOMMENDATIONS:}

Future studies should try to incorporate prospective data collection, long term followup and validated disease specific SE instruments. Replication and expanded studies are needed for hemodialysis patients.

\section{REFERENCES:}

Abd Elazeem, N. (2008): Compliance of patients on Hemodialysis with Therapeutic Regimen, M.SC. Faculty of Nursing Ain Shams University, P.18.

Abd-El hamed, HM. (2011): Impact of Teaching Guidelines on Quality of Life for Hemodialysis Patients, Nature and Science;9(8), Pp.2014-22.

Afifi, A., Refaat, H., Wahba, AM. , Karim, MA. , El Sharkawy, M., Ramadan, A., Aziz, A., and Fayez, R. (2002): Hemodialysis vascular access among chronic renal failure patients in Egypt, The Journal of Vascular Access; 3(4):Pp.164-168.

Ahmed, AM., Allam, M., Habil, ES., Metwally, AM., Ibrahiem, NA., Radwan, M., El-Gaafary, MM., Afifi, A., and Gadallah, MA. (2010): Development of practice guidelines for hemodialysis in Egypt, Indian J Nephrol.; 20(4): Pp.193-202.

Akin, S., Can, G., Durna, Z. and Aydiner, A. (2009): Preliminary testing of a turkish version of the strategies used by patients to promote health (supph) scale in a sample of breast cancer patients, Journal of Nursing and Healthcare of Chronic Illness; 1, Pp.303-310. 
Aliasgharpour, M., Shomali, M., Moghaddam, MZ., Faghihzadeh, S., (2012): Effect of a self-efficacy promotion training programme on the body weight changes in patients undergoing haemodialysis. Journal of Renal Care xx(xx), Pp.1-7.

American Kidney Fund. (2016): American Kidney Fund, American Kidney Fund, Inc. Available at: http://www.kidneyfund.org/kidney-disease/kidney-failure/ Accessed on: 13/1/2016.

Anees, M., Hamed, E., Mumtaz, A., Ibrahim, M., and Khan, MNS. (2011): Dialysis related factors affecting quality of lifein patients on hemodialysis, Iranian journal of kidney disease; 5: Pp.9-14.

Badheeb, AM. (2006): Causes of Chronic Renal Failure in Hemodialysis Unit: a single center experience in Yemen, Saudi journal of kidney diseases and transplantation: an official publication of the Saudi Center for Organ Transplantation, Saudi Arabia; 17(1): Pp.66-9

Bandura, A. (1982): Self-efficacy mechanism in human agency. American Psychologist; 37, Pp.122-147.

El-Sayed, MM. (2007): Nurses Role in Managing Complications of Patients on Hemodialysis. M.Sc.N Thesis, Faculty of Nursing, Ain Shams University. pp.147148,154 .

Hamed, N. (2001): Rehabilitation program to improve Quality of life for patients undergoing renal disease, M.D.SC Faculty of Nursing Ain Shams University.

Heidari, M., Alhani, F., Kazemnejad, A., Moezzi, F. (2007): The effect of empowerment model on quality of life of Diabetic adolescents., Iran J Pediatr; 17(1): Pp.87-94.

Lin, Ch., Wu, Ch., Anderson, R., Chang, Ch., Chang, Sh., Hwang, Sh., and et al. (2012): The chronic kidney disease self-efficacy (CKD-SE) instrument: development and psychometric evaluation, Nephrol Dial Transplant.; 27(10), Pp. 3828-3834. Available at: http:// www.ncbi.nlm.nih.gov/pubmed/?term=Anderson RM(auth) accessed on 15/11/2013. 
Lutf, $\boldsymbol{A}$ A . (2007): Effect of a Nursing Rehabilitation Program on Quality of Life Among Patients Undergoing Hemodialysis. DNSc. Thesis, Faculty of Medicine and Health Sciences, Sana'a University, Yemen, PP.1-17, 5057.

Mohamed, MM. (2007): Self-Care Learning Package: Effect on Patients' Quality of Life Undergoing Hemodialysis Therapy. D.N.Sc. Thesis, Faculty of Nursing, Ain Shams University. P. 139.

Sharaf, AY., Eweda, SM., EL-Belbessi, AS., and Salem, MA. (2004): Assessment of nursing interventions intradialytic problems of patients are maintenance hemodialysis, Kid dis; 3(1), Pp. 103-17.

Shinde, M., and Mane, SP. (2014): Stressors and the Coping Strategies among Patients Undergoing Hemodialysis, International Journal of Science and Research (IJSR); 3(2): Pp. 2319-7064.

Soliman, AR., Fathy, A., and Roshd, D. (2012): The growing burden of end-stage renal disease in Egypt, Epub; 34(4), Pp.8-425. doi:10.3109/0886022X.2011.649671.

Song, MR. (2000): The Development and Test of Self-Efficacy Promotion Program on Self-care of Hemodialysis Patients, J Korean Acad Nurs.; 30(4): Pp.1066-1077.

Thomas-Hawkins, C., and Zazworsky, D. (2005): Self-management of chronic kidney disease. AJN.; 105(10):Pp.40-48.

Tsay, SL. (2003): Self-efficacy training for patients with end-stage renal disease, Blackwell Publishing Ltd, Journal of Advanced Nursing; 43(4), Pp.370-375.

Weisbord, SD., Fried, LF., Arnold, RM., Fine, MJ., Levenson, DJ., Peterson, RA., and Switzer, GE. (2007): Prevalence, severity and importance of physical and emotional symptoms in chronic hemodialysis patients. Available at: http:// www.jasn.org/ Accessed on: 22/5/2015. 


\section{تأثير الإرشادات التعليمية علي الكفاعة الذاتية لاي مرضي أمر اض الكلي بمر احله الأخيرة الخاضعين للغسيل الكلوي

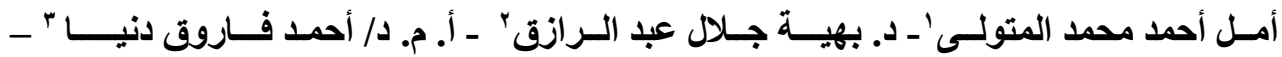 \\ أ.د. مساجدة عبد العزيز محمدء

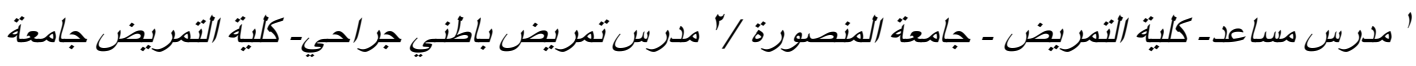

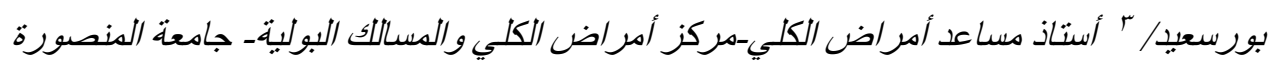

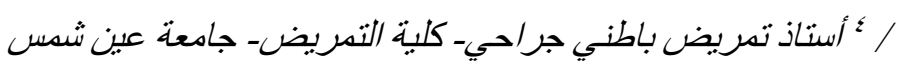

\section{الــــلاصــة}

تتطور امر اض الكلي بمراحله الأخيره مع أو بدون عوامل خطورة وبالرغم من ذلك كلما زاد وجود عوامل الخطورة، كلما زاد معدل تطور ها. كان الهدف من هذه الدراسة تقييم تأثير الإرشادات التعليميه علي الكفاءة الذاتيه لدي مرضي أمر اض الكلي بمر احله الأخيره. تم عمل دراسة شبه تجريبية مع تقييم قبلي وبعدي في هذه الدراسة. أجريت هذه الدراسة علي عينة مناسبة والتي شملت (• م مريض) و الخاضعين للغسيل الكلوي. وقد أجريت هذه الدراسه بمركز الكلي و المسالك البوليه بجامعة المنصورة. وتثمل أدوات جمع البيانات أداتين: الاولي ورقة استنبيان باللغة العربية وتتكون من جزئين البيانات الاجتماعية والديمو غر افية والتاريخ المرضي للمريض و الثانية مقياس الكفاءة الذاتية لمرضي الكلي المزمن. وقد أظهرت نتائج هذه الدراسة ظهور تحسن إيجابي إحصائي ملحوظ في في مستوي الكفاءةالذاتية لأفراد العينة المدروسة. وأوصت الدراسة أنه يجب علي الابحاث المستقبلية دمج جميع الييانات المستقلية و المتابعة على المدى الطويل والادوات المحقق من صحتها عن الكفاءة الذاتية وضرورة تكرار الدر اسات و الأبحاث لمرضى الغسيل الكلوي بشكل أوسع نطاقاً.

الكلمات المرشدة: أمر اض الكلي بمر احله الأخيره، الغسيل الكلوي، الكفاءة الذاتية، الإرشادات التعليمية 